\title{
Shoreline Changes and Coastal Erosion: The Case Study of the Coast of Togo (Bight of Benin, West Africa Margin)
}

\author{
Francesco Guerrera ${ }^{1}\left(\mathbb{D}\right.$, Manuel Martín-Martín $\left.{ }^{2}{ }^{(}\right)$, Mario Tramontana ${ }^{3, *} \mathbb{C}$, Bertin Nimon $^{4}$ and \\ Kossi Essotina Kpémoua ${ }^{5}$ \\ 1 Formerly Belonged to the Dipartimento di Scienze della Terra, della Vita e dell'Ambiente (DiSTeVA), \\ Università degli Studi di Urbino Carlo Bo, 61029 Urbino, Italy; francesco@guerrera.biz \\ 2 Departamento de Ciencias de la Tierra y Medio Ambiente, University of Alicante, 03080 Alicante, Spain; \\ manuel.martin.m3@gmail.com \\ 3 Dipartimento di Scienze Pure e Applicate (DiSPeA), Università degli Studi di Urbino Carlo Bo, \\ 61029 Urbino, Italy \\ 4 Regenyal Laboratories srl, 63074 San Benedetto del Tronto, Italy; mawekiwe@gmail.com \\ 5 Institut Togolais de Recherche Agronomique (ITRA), Cacavéli, Lomé BP 1163, Togo; \\ kossi.kpemoua@gmail.com \\ * Correspondence: mario.tramontana@uniurb.it
}

Citation: Guerrera, F.;

Martín-Martín, M.; Tramontana, M.; Nimon, B.; Essotina Kpémoua, K. Shoreline Changes and Coastal Erosion: The Case Study of the Coast of Togo (Bight of Benin, West Africa Margin). Geosciences 2021, 11, 40. https://doi.org/10.3390/geosciences 11020040

Received: 17 October 2020

Accepted: 14 January 2021

Published: 21 January 2021

Publisher's Note: MDPI stays neutral with regard to jurisdictional claims in published maps and institutional affiliations.

Copyright: (C) 2021 by the authors Licensee MDPI, Basel, Switzerland. This article is an open access article distributed under the terms and conditions of the Creative Commons Attribution (CC BY) license (https:// creativecommons.org/licenses/by/ $4.0 /)$.

\begin{abstract}
The coastal strip between the Volta River delta and the westernmost portion of Benin (West Africa Margin of Atlantic Basin) is highly populated (e.g., Lomé) due to migrations from inland areas. The coastal zone has proved to be very vulnerable because of the potential development of sometimes catastrophic events related to different and interacting causes, resulting in negative effects on natural ecosystems and socio-economic conditions. The main problem is the marked erosion of large coastal sectors with maximum retreat rates of the order of $5 \mathrm{~m} /$ year. The continuous loss of territory leads to a progressive impoverishment of activities and human resources and to the increase of geological risk factors. The coastal erosion is induced both by natural and anthropic causes and can be controlled only by means of prevention programs, detailed scientific studies and targeted technical interventions. The main erosional processes observed in the study area are triggered by the presence of the Lomé port and other human activities on the coastal strip, including the water extraction from the subsoil, which induces subsidence and the use of sediments as inert material. These elements, together with the reduction of the solid supply from Volta River (caused by the realization of the Akosombo dam) are among the main factors that control the medium and long-term evolution of the area. Also relative sea level changes, which take into account also tectonic and/or isostatic components, can contribute to the process. In order to have a real understanding of the coastal dynamics and evolution, it would be necessary to develop a scientific structure through the collaboration of all countries of the Bight of Benin affected by coastal erosion. The aim should be primarily to collect the interdisciplinary quantitative data necessary to develop a scientific knowledge background of the Bight of Benin coastal/ocean system. In conclusion, some proposals are presented to reduce the vulnerability of the coastal area as for example to plan surveys for the realization of appropriate coastal protection works, such as walls, revetments, groins, etc. A possible expansion of the port of Lomè is also considered. Proposals comprise the constitution of a Supranational Scientific Committee as a coordinating structure on erosion for both the study of phenomena and planning interventions.
\end{abstract}

Keywords: coastal zone; erosion; natural and anthropogenic factors; coastal protection; Togo

\section{Introduction}

The pronounced indented coastline of Gulf of Guinea (East Atlantic Ocean) constitutes the Bight of Benin (about $640 \mathrm{~km}$ wide) where Togo, Benin, Ghana and part of Nigeria (Western Africa) face. Togo is a small western Africa nation covering approximately 
$57,000 \mathrm{~km}^{2}$ and with about 7.8 million inhabitants (2017 data), independent since 1960. The coast of Togo (Figure 1) extends for a short stretch of about $56 \mathrm{~km}$ in length, where the capital Lomé is located with about 850,000 of inhabitants.

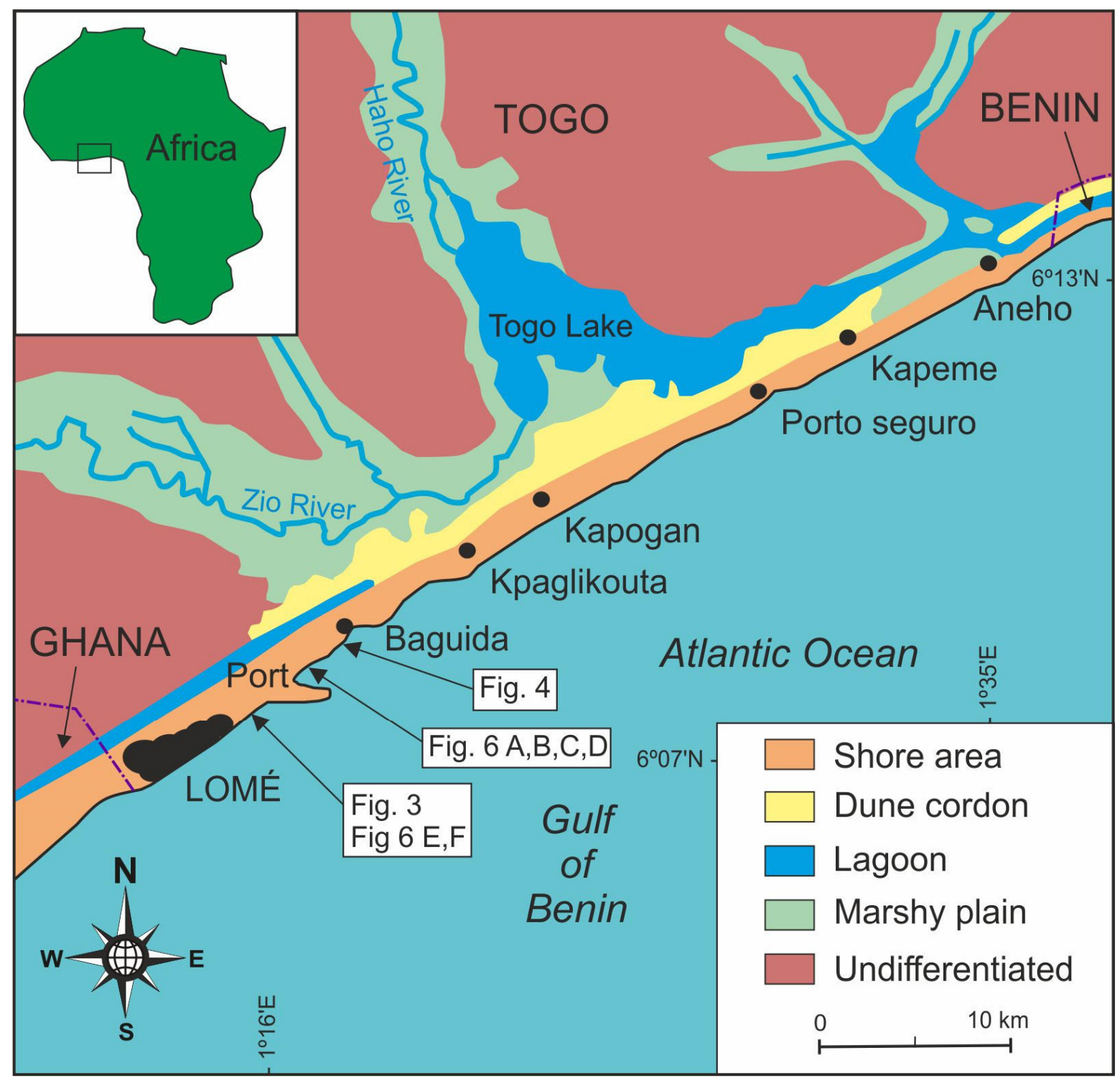

Figure 1. The coast of Togo and neighboring areas (eastern Ghana and western Benin), and some localities mentioned in the text (after [1]), modified).

The interaction between natural processes and anthropic activity often turns into coastal erosion especially in correspondence of areas that show geological and geomorphological vulnerability and not adequately protected. The coastline tends to retreat progressively, so creating significant problems for the socio-economic management of different areas at risk. The amount of retreat is variable, and in some places a maximum value of about $130 \mathrm{~m}$ for the last 40 years (Satellite images Landsat $4,5,8$ ) is recognizable, as for example immediately to the east of the Lomè port. The main storm events directly controlled the erosion rate.

The erosion has already caused a marked reduction of the coastal strip, thus also affecting anthropized areas. The persistence of the current negative evolutionary trend will increasingly compromise the eastern area of the capital Lomé and of other urbanized areas located on the coastal area that extends up to Benin and beyond. 
The disastrous impact of this process on at least a part of the population of Lomé (about 850,000 inhabitants) would involve socio-economic interests of national importance and would result in an obliged migratory counter-outcome towards the hinterland. Some villages and rural areas of the coastal fringe have already been wiped out, due to the high retreat rate. Lomé airport, which was inaugurated in 2016, could also be threatened in the not too distant future.

The coastal erosion has worried the local people. In the Gbodjomé area $(23 \mathrm{~km}$ east of Lomé), some initiatives (i.e., the covering of stretches of beach with blocks of rocks) were developed by the population. In fact, a civil society group mobilized resources aimed to prevent the advance of the sea.

A first coastal protection was realized with three million of sandbags arranged to protect the shore, but they did not resist the wave energy. Also close to the eastern pear of the port of Lomè the beach was protected by breakwaters. Artificial breakwaters represent the few other solutions adopted so far. These protection works were realized in some areas a few hundred meters long coastal such as: (i) immediately behind the west pier of the port of Lomé, and (ii) the coastal sector located between Gunukopé and Aného where the protections are producing coastal nourishment [1].

Since 2008, the Togo Government adopted initiatives for environmental management and protection of natural resources, but they still have not been enough. Coastal protection technical implementations were designed and supervised by the INROS LACKNER AG [2]. Environmental experts from 16 coastal countries of the Large Marine Ecosystem of the Guinea Current (GEMCG) Region met in Lomé (2011) to adopt a common position to deal with the coastal erosion. In fact, the coastal modifications concern not only the Togo area, but also other countries of the Gulf of Guinea and in particular Nigeria, Benin, Ghana, Ivory Coast and Liberia. The participants adopted a document, which provides detailed scientific information to identify and deal with causes of erosion.

To better frame the problem, it is necessary to prioritize studies aimed at identifying the different causes of erosion, their effective control on erosional processes and then realize appropriate interventions. In this context, the coast of Togo can be considered a "key case" to better evaluate the erosional phenomena and the related loss of soil, plants and coastal infrastructures.

The aim of this interdisciplinary work is: (i) to frame and better describe erosional processes that affect most of coasts of Togo and neighboring areas; (ii) to identify the main causes of coastal geomorphological modifications, distinguishing natural factors (e.g., geological vulnerability, hydrodynamics, etc.) and anthropogenic ones (e.g., immigration, land use, etc.); (iii) to evaluate the major causes of erosion on the basis of resulting effects; (iv) to suggest technical evaluations and to favor the planning of a permanent technical-scientific staff addressed to stem the loss of territory, and to reduce economic and social damages. The institution of a transnational authority is also suggested.

Given the complexity of the considered phenomena, in the above-mentioned perspective it is however necessary to cross the results from different scientific studies with the aim to increase the knowledge by means of interdisciplinary interpretations and to plan appropriate scientifically-based interventions.

\section{Study Area}

The coast of Togo is a low and sandy coast, similar to those of neighboring countries. The inland is for about $30-40 \mathrm{~km}$, a hilly region where an altitude of $100-200 \mathrm{~m}$ is reached. The relief found more towards the hinterland is a $400 \mathrm{~m}$ high plateau with a typical senile aspect, on which the Togo Mountains rise $(1020 \mathrm{~m})$. This sub-meridian oriented ridge separates the Niger River basin from the Volta river basin, constituting a characteristic morphological element. Northwest of the Togo Mts the altitude decreases, in correspondence with the middle course of the Oti river basin. The orographic axis of the Togo Mts separates the Mono river basin from the Oti river basin. 
The coastal area is protected by a beach/barrier beach and littoral dunes, which delimitate lagoon areas, ponds, marshes and small coastal lakes. The mouth of the Mono River marks the border between Togo and Benin. The lagoon area reaches its maximum depth in Porto Séguro, where the lagoon widens to form a real and large coastal lake (Togo Lake).

The coastal sedimentary strip is characterized by three distinct irregular aquifers: (1) the shallowest aquifer is found in the continental sand and gravel deposits; (2) the intermediate one is found in the Eocene-Paleocene sands and limestones; (3) the deepest aquifer is found in the Cretaceous sands (Maastrichtian). The first aquifer is the most exploited mainly for domestic uses, due to easy capture of water.

The coastal area of Togo represents a natural dynamic system where the beach evolution is controlled by different natural and anthropic factors, which cause shoreline recession (erosion) and/or advance, depending on prevailing processes. Wind, waves and marine currents are natural processes that easily move the unconsolidated sediments along the beach, causing rapid modifications. Small-scale processes such as storms, wave action, tides and wind control the short-term beach evolution; the long-term evolution depends on large-scale processes such as climate changes and tectonic activity, the latter causing vertical movements which may contribute to relative sea level variations.

As synthetically shown in Figure 1, the flat coast of Togo is characterized by a beach/barrier beach system. The coast is affected by marked erosion mainly due to the construction of the port of Lomé. Many anthropic settlements are located in the area and they result in a strong anthropogenic pressure along the land/sea interface, which represents a very fragile environment.

The coast of Togo represents the main investigated area in the present work. In the area (Figure 1) field analyses were carried out, which become more intensive and repeated over time in the last seven years. Other occasional field observations have also been made in the easternmost shore portion of Ghana (up to the Volta river) and in the western shore portion of Benin (west of Cotonou). The choice of the study area depended on contingent factors linked to bureaucratic difficulties in order to operate in the different areas of interest. The major facilities have been obtained from the Togolese Government and for this reason the research has been prevalently addressed to the coastal strip of this country.

The literature available for the area refers to very different topics (e.g., [3-12]). These authors were directly interested in the same area considered in the present paper. However, the problem of coastal erosion and both its natural and anthropic causes is a great and important problem, which many other coastal countries in the word are experiencing. Therefore, this complex problem has been studied in many other oceanic and internal sea areas (e.g., [13-20] among others).

Geomorphological analyses have been carried out in selected areas of Ghana for largescale assessment of coastal erosion [Boateng, 2012 [21]]. This author identified large areas of erosion, characterized by variable recession rates, which caused along the east coast of the Volta River delta the loss of settlements built between 1961 and 1965 (Keta and Ada).

The morphology of the submerged area of Togo is characterized by a narrow continental shelf (10 km wide on average) showing an abrupt slope around the $100 \mathrm{~m}$ isobath. A fossilized coral reef is present offshore, in the continental shelf. The seabed consists mainly of sands, and is characterized by two rocky areas. The soft sea bottom consists of often-mixed sand and mud; the rocky sea bottom is represented by small zones, which are colonized by gorgonians and located at depth less than $15 \mathrm{~m}$ (near Doèvi). Outside the lagoon inlets, the sandy bottoms extend up to a depth of about $35 \mathrm{~m}$; the sandy mud bottoms, which are dotted by corals, are located at a depth ranging from $45 \mathrm{~m}$ to $52-56 \mathrm{~m}$.

Beach sediments are supplied mainly by the Volta River, and by wave erosion both of coastal sectors and seabed. Sediments are redistributed by coastal currents and are re-deposited along the coast. According to the main longshore current direction, the mainly prevalent transport was found to be from west to east. 
From a geological point of view, Togo is a part of the West Africa geological complex, which includes two main units: (i) the pre-Paleozoic basement forming the African craton; (ii) the sedimentary cover consisting of heterogeneous successions, which range in age from Proterozoic to Present.

The territory prevalently consists of a pan-African pre-Cambrian fragment slightly reactivated by subsequent orogenic cycles. Different pre-Cambrian units (mica-schists, gneiss, quartzites, with granite intrusions) of the continental basement are recognizable in the E and S sectors of the country, while Paleozoic units are common in the W and $\mathrm{N}$ sectors.

The sedimentary cover that characterizes the coastal zone of Togo (Figure 2) is represented by units belonging to the "Coastal Sedimentary Atlantic Basin". The deposits of this basin are detritic successions derived from the dismantling of previous deformed rocks and are divided into "Infratillite" and "Supratillite" supergroups. The first one is constituted by green arenites with carbonate cement, followed by the Bombouaka arenites, up to the Nayéga Manganesiferous beds; successively, the sedimentation gives way to a period of glacial erosion marked by an unconformity surface buried by tillites and mixtites of about $700 \mathrm{Ma}$. The "Supratillite" sedimentary cycle starts with tillites, carbonate deposits and chert beds followed by the Mango Shales (about $660 \mathrm{Ma}$ ) and the Gando Arenites. In particular, deposits characterized by basal upper Pleistocene river sands to Holocene estuarine and fluvial-deltaic sands [22] are present in the coastal area. The tectono-sedimentary evolution of the "Coastal Sedimentary Basin" starts with a subsidence caused by oriented in a sub-meridian direction extensional faults (opening phase, graben structures), which mark a tectonic mobility testified also by the presence of volcano-sedimentary deposits and a thick detritic deposition [23]. Lateral thickness and/or lithofacies variations of the original basinal deposits are probably linked to the relative distance of the supply zones, depending on tectono-metamorphic events developed in different times (pan-African phase).

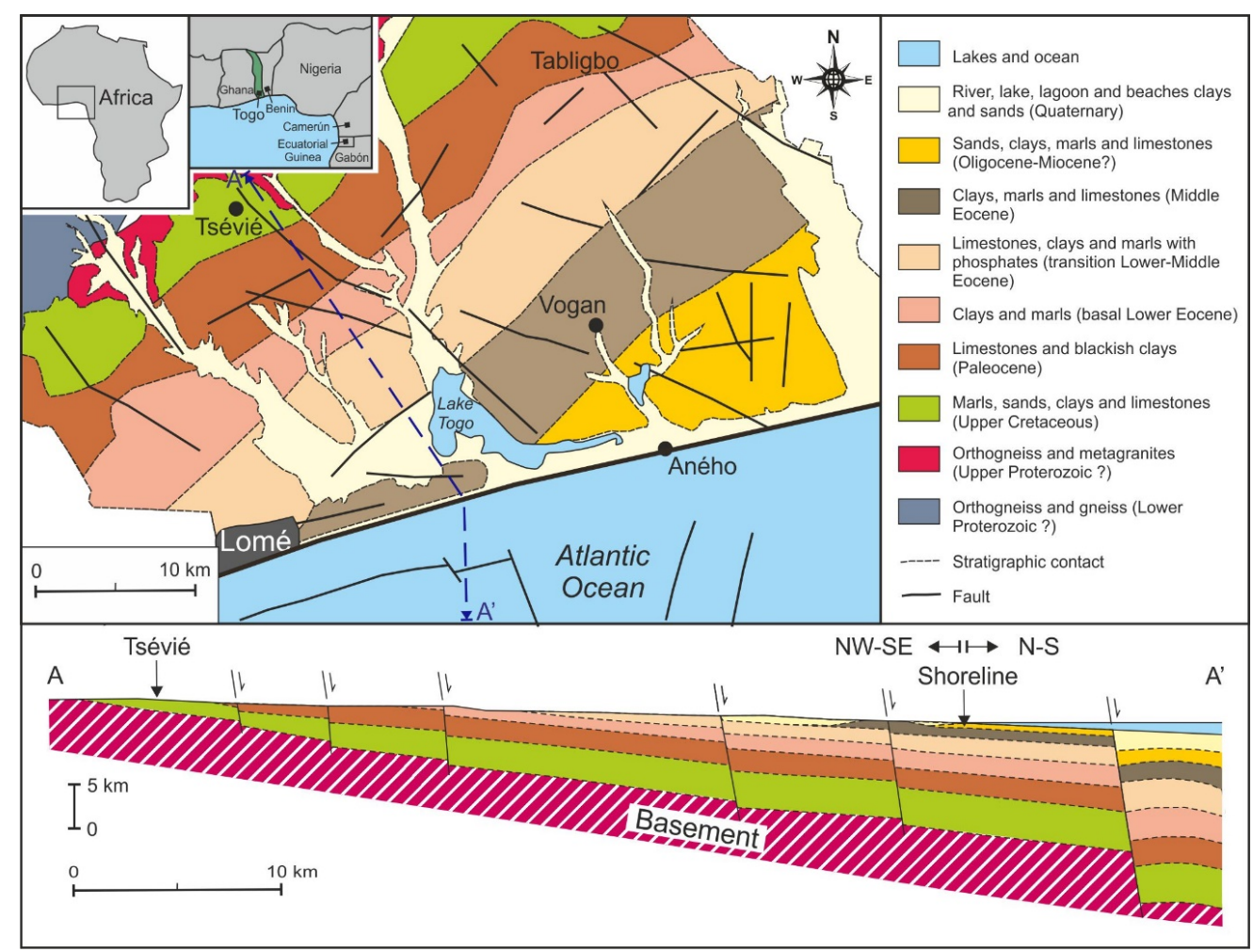

Figure 2. Geological sketch map of the Togo margin of the Atlantic Ocean, and geological cross section across onshore and offshore areas (after [23], modified). 
The coastal sedimentary Atlantic Basin belongs to a passive margin resulting from the intersection between sub-meridian oriented structures (Pan-Africa Dahoméyides Chain) and the transversal structures described by Guiraud, 1986 [24] as Central-African lineaments. These latter structures show a general trend of $\mathrm{N} 70^{\circ} \mathrm{E}$, and are superimposed on late-Pan African structures (brittle tectonics). The general strike of structures of the coastal basin (between $\mathrm{N} 50^{\circ} \mathrm{E}$ and $\mathrm{N} 70^{\circ} \mathrm{E}$ ) represents a major paleogeographic direction that influenced the basin development and filling. The Adina fault of Lomé, which corresponds to one of the late-Pan African structures, was an active left (?) hand strike-slip fault from the Cretaceous up to the opening of the Guinea Gulf. Toward south, the Romanche fracture, which belongs to the same family of structures, separates a northern suspended basin encompassing the onshore and offshore basins of Togo from another southern deep basin located on oceanic crust [25].

As regards the oceanographic characters of the area, different types of marine currents are present: (i) west to east flowing offshore Guinea current; (ii) tidal currents; (iii) westeast flowing wave related longshore currents, with a transport capacity resulting into a shoreline drift of sediments of 1.2-1.5 $\times 10^{6} \mathrm{~m}^{3} /$ /year. As regards the clastic sediment supply, a reduction over time was caused by the presence of the Akosombo and Nangbéto dams. Observations in the Dzita, Keta and Ada localities (Ghana) indicate a particularly severe erosion (cfr. Caunt, 2016 [26]).

The Guinea current is a slow warm water surface current that flows offshore from west to east with an average speed ranging between $1 \mathrm{~m} / \mathrm{s}(\max .1 .5 \mathrm{~m} / \mathrm{s})$ in summer and $0.5 \mathrm{~m} / \mathrm{s}$ ( $\max .0 .75 \mathrm{~m} / \mathrm{s}$ ) in winter. This current becomes weaker moving toward the east [27]. The south-west monsoon is persistently modified by land breezes and sea breezes. The semi-diurnal tide is uniform with an average value of about $1 \mathrm{~m}$. In particular, the tidal excursion ranges from 0.9 to $1.5 \mathrm{~m}$, which is the value normally found in the Bight of Benin. The tide swell is regular and directed toward SSW. Tidal currents can move the sea bottom sediments. Values of sea level fluctuations due to particular meteorological (wind and atmospheric pressure) and oceanographic (rise in the average level of water inflow from waves) conditions may be superimposed to tides, resulting in temporary surges.

The coastal waves originate by the local monsoon wind and by storms generated in the southern part of the Atlantic Ocean. The average significant wave height is $1.36 \mathrm{~m}$, with a peak period of $9.4 \mathrm{~s}$ and a dominant SSW direction $\left(189^{\circ}\right)$ [27]. The seasonal modulation of waves is weak, showing a wave height peaking at $1.6 \mathrm{~m}$ during the austral winter. On the contrary, the annual average wind wave height is shorter $(0.4 \mathrm{~m})$ and the direction is more westward $\left(215^{\circ}\right)$

Togo is schematically divided into two climatic regions: (a) the northern region, which is characterized by a climatic regime that is similar to the Sudanese tropical one, with a single rainy season corresponding to the boreal summer (from May to October) and a dry season; (b) the southern region, which is marked by a subequatorial climate with two rainy seasons (extending from March to June and from September to October) alternating with two dry seasons.

The annual average rainfall ranges from $800 \mathrm{~mm}$ (Lomé and coastal fringes) to $1400 \mathrm{~mm}$ (Atakpamé region, southern-central Togo), but on reliefs of the Atacora chain the climate is as the Guinea one, with rainfall varying from 1500 to $1800 \mathrm{~mm}$.

The coast of West Africa is characterized by an equatorial climate (Giardino et al., 2018 [28], p. 251) showing considerable differences in the seasonal amount of precipitation [27], but the eastern part of the coast is considerably drier than the western one. The main rivers of the region are the Pra and Volta rivers (Ghana), the Mono River (Togo), and the Oueme River (Benin), but only the Volta River represents a main source for sediment supply.

The hydrography of the considered coastal area includes the Zio and Haho rivers, which drains an area of about $1800 \mathrm{~km}^{2}$ and flow into the Togo Lake. The southern rivers of Togo originate from the Atacora chain (Togo Mts) and their contribution to the fluvial terrigenous supply can be considered irrelevant. 
The coastal indentation of the Bight of Benin tends to weaken the seasonal contributions of the ocean originated humid air and to determine the appearance of continental climate contributions.

The coastal fringe has a humid tropical climate showing low annual average temperatures $\left(20\right.$ to $25^{\circ} \mathrm{C}$ ), but it is also characterized by two dry seasons that divide the rainy season into two periods extending from March to July and from September to October, respectively. The relative humidity is constantly high throughout the year. Nevertheless, the city of Lomé (Lat. $6^{\circ} 10^{\prime} \mathrm{N}$ ) has a relatively dry climate. Lomé shows a microclimate marked by a stable temperature (without excessive peaks) strongly mitigated by the ocean wind and a relatively low rainfall $(800 \mathrm{~mm} /$ year$)$.

Four factors combine to create this climate anomaly in the Bight of Benin: (i) the orientation of the coast, which is almost parallel to the flow of the southwestern monsoon, does not favor the ascending air. As a result, this factor prevents coastal rainfall; (ii) the inter-tropical front located at the Sahelian latitudes determines in southern Togo a stable monsoon in July-August. This produces high humidity and a lack of rainfall; (iii) the presence of the harmattan wind toward the coast during December-February amplifies the rain impediment; (iv) the cold Benguela marine current along the Togolese coasts in August causes the cooling of surface water (the temperature drops from $28^{\circ} \mathrm{C}$ to $20^{\circ} \mathrm{C}$ ), preventing any evaporation and therefore any precipitation. The average thermal data over the last 45 years show a progressive increase of temperature from $0.5^{\circ} \mathrm{C}$ to $1.1{ }^{\circ} \mathrm{C}$, at least. The decrease of rain in Lomé in the period 1986-2005 with respect to the 1961-1985 was of the order of $114 \mathrm{~mm}$, with a reduction of 14 days of rain, to testify a climate aridification trend.

Concerning the relative sea level changes, the possible sea level rise would activate negative processes resulting into coastal risks related to: (i) the amplification of coastal erosion; (ii) the increase of marine ingression problems (submersion); (iii) the increase of intrusion of saline waters (saline wedge) into groundwater coastal aquifers and the salinization of river mouths and lagoons, which can cause major changes in coastal aquatic and terrestrial ecosystems.

\section{Materials and Methods}

The coast of Togo and some portions of eastern Ghana and western Benin have been examined. In particular, the coastal strip between the port of Lomé and the Benin border was analyzed in detail due to its acclaimed storm vulnerability.

A multidisciplinary approach has already been used in the present study during the first recognition on processes involved. This phase of the work aimed to carry out preliminary field observations and to collect some quantitative data to better frame the amount of the active erosion.

The study developed includes specific questions concerning a better knowledge of erosion phenomena and the definition of the main causes in different coastal sectors. Moreover, suggestions to reduce the loss of territory are presented. The interdisciplinarity of the work is mainly based on:

1. Preliminary background information from: (i) internal reports (usually not published) from technical and administrative archives; (ii) internet information; (iii) scientific literature; (iv) general field controls;

2. Literature data concerning (i) the fluvial regime and the detrital supply evaluation; (ii) the sea-level changes; (iii) the artificial water dams;

3. Geological, sedimentary and tectonic information and reconstructions of the Togo coastal sector and neighboring areas;

4. Field observations on coastal area repeated annually in the period 2014-2020 and addressed to recognize (i) the evolution, amount of erosion and erosional features; (ii) the beach extension, topography and morphology. In particular, investigation were aimed to define (i) the shoreline position; (ii) the beach width, measured evaluating the shoreline distance from fixed points located in the mainland; (iii) the amount of shoreline position changes; (iv) the possible variation of the transversal beach profile; 
(v) the shoreline orientation and straightness; (vi) the presence of backshore erosion or depositional features such as steps and berms.

5. Sampling of beach sediments (January 2020) for grain size analyses. Some samples (see Section 4.2) were collected in the beach sectors located west and east of the port of Lomè, which today are experiencing growth and erosion, respectively;

6. Geomorphological observations carried out also by means the interpretation of satellite images and collection of literature information concerning (i) the long-shore sediment transport and coastal currents; (ii) the impact on coastal area of the main anthropic structures (port, roads, etc.). In particular, the satellite images considered (Landsat 4, 5 and 8) pointed out the coastal sectors experiencing the strong erosion and allowed evaluating the rate of the coastal retreat for the last 40 years. Values of retreat were estimated with respect to a reference base line placed at the top of a relief, which is located on average at several tens of metres from the shoreline, and whose top emerges during low tides.

Some proposals of activities and possible interventions aimed at mitigating the erosion phenomena are presented at the end of the paper. Suggestions are based on the present features and setting of the considered coastal area. However, for the effective choice of protection works to be realized, it will be necessary to also consider the relative sea level rise expected for subsequent decades. In fact, the possible occurrence of this phenomenon will imply political and economic choices, which are difficult to evaluate at present.

The paper is based also on the geological map and related explanatory notes of Togo [23].

The above-mentioned field observations and analyses were compared and integrated with the information from literature, websites and unpublished internal reports, mainly as regards the neighboring areas of Benin and Ghana.

Previous knowledge, together with the new data collected in 2014-2020, allowed for identifying the main processes that control the strong erosional processes especially along the coast of Togo.

\section{Results}

In this section the main results about processes affecting the coast of Togo and surrounding areas are described.

\subsection{Outcomes from Field Observations}

Around $56 \mathrm{~km}$ of the coast of Togo have been subdivided into four main geomorphological subsystems, and opposite evolutionary trends were observed to the east and west of the Lomé port, respectively. Figure 3 shows the expanding beach to the west of the port of Lomè, while Figure 4 shows clear examples of severe beach erosion to the east of the port. The approximately $10 \mathrm{~km}$ of the western coast of Togo are clearly characterized by a growing beach extending with a variable width up to some hundreds of meters (Figure 3). In this area the sedimentary balance between materials removed and sediment supplied is in favor of the latter. It implies that factors that may cause coastal erosion (e.g., tectonics, geomorphological, climatic, hydrodynamic, anthropic factors, etc.) act subordinately. Some observations suggest that despite the reduction of the clastic contribution to the sea, which is partially retained by the dams system built on Volta River (Ghana), the sedimentary balance is positive because the amount of sediment supply due to longhshore currents is, however, enough to compensate the reduction and to nourish the beach. The Volta River represents a major sediment source of the area and sediments are redistributed along several hundred kilometers of coast. In spite of the massive volume of sand drifting eastward (considered 1.2-1.5 $\times 10^{6} \mathrm{~m}^{3} / \mathrm{yr}$ by Blivi et al., 2002 [22]), the delta progradation slowed down to reach a substantial equilibrium between the hydrodynamic regime and the coastal geometry, as the result of the same amount of incoming sediments with respect to the outcoming clastic supply. The latter includes the amount of sediments redistributed along the Togo and Benin coasts. This ancient dynamic stability has been disturbed mainly 
by the construction of the port of Lomé, which reaches deep waters and caused a change of the coastal dynamics and the general growth of the beach stopping abruptly down-drift from the structure. In general, the longshore currents determine a predominant direction of sand transport from west to east, but this coastal drift is at present interrupted by the western side of the Lomè port. Therefore, the west piers favored the accumulation of sandy deposits, while strong erosion developed to the east of the port.
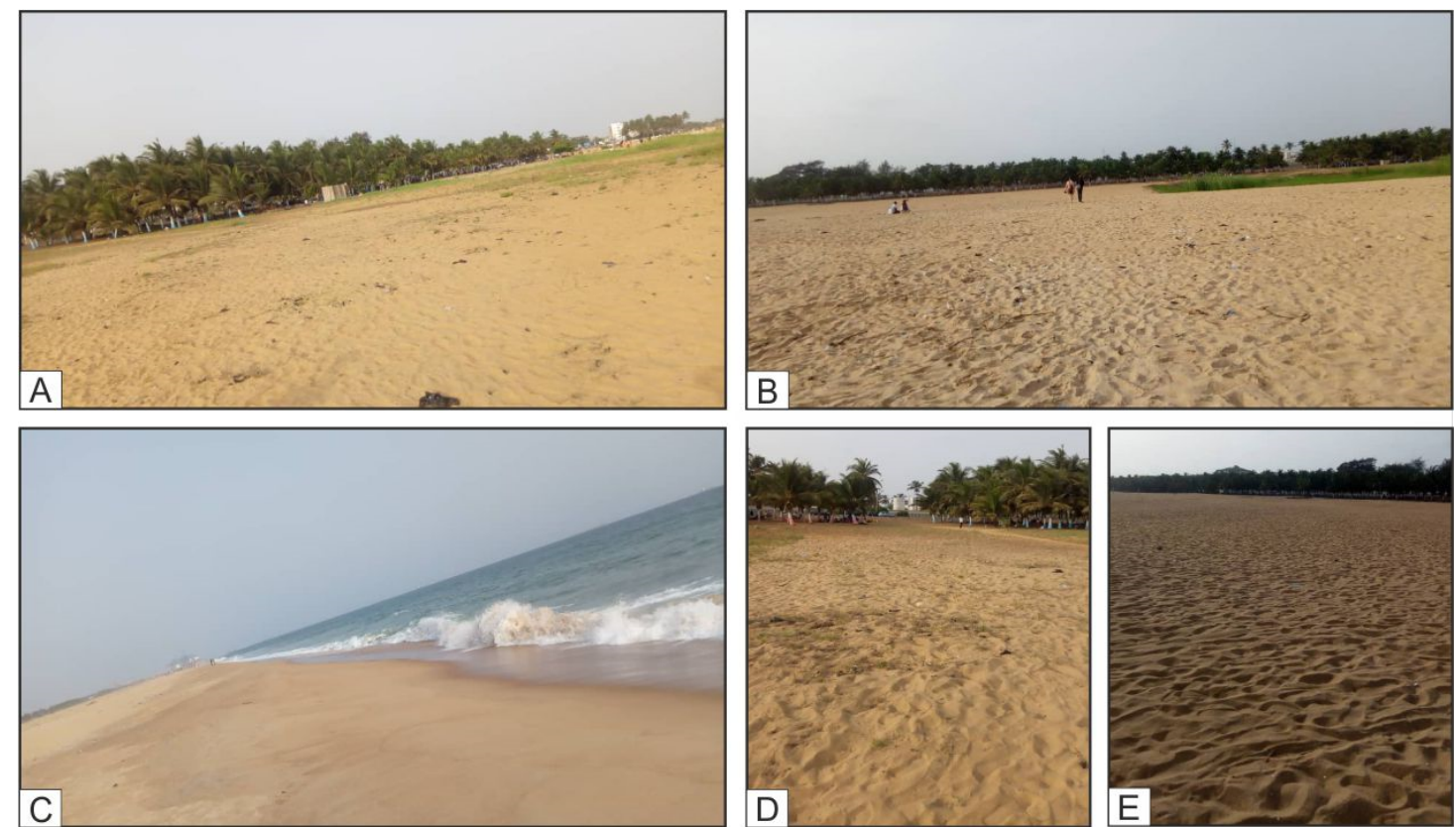

Figure 3. Geomorphological features (A-E) of the about $400 \mathrm{~m}$ wide expanding beach located to the west of the Lomé port. The beach is often bounded by vegetation including trees (Photographs December 2019-January 2020).
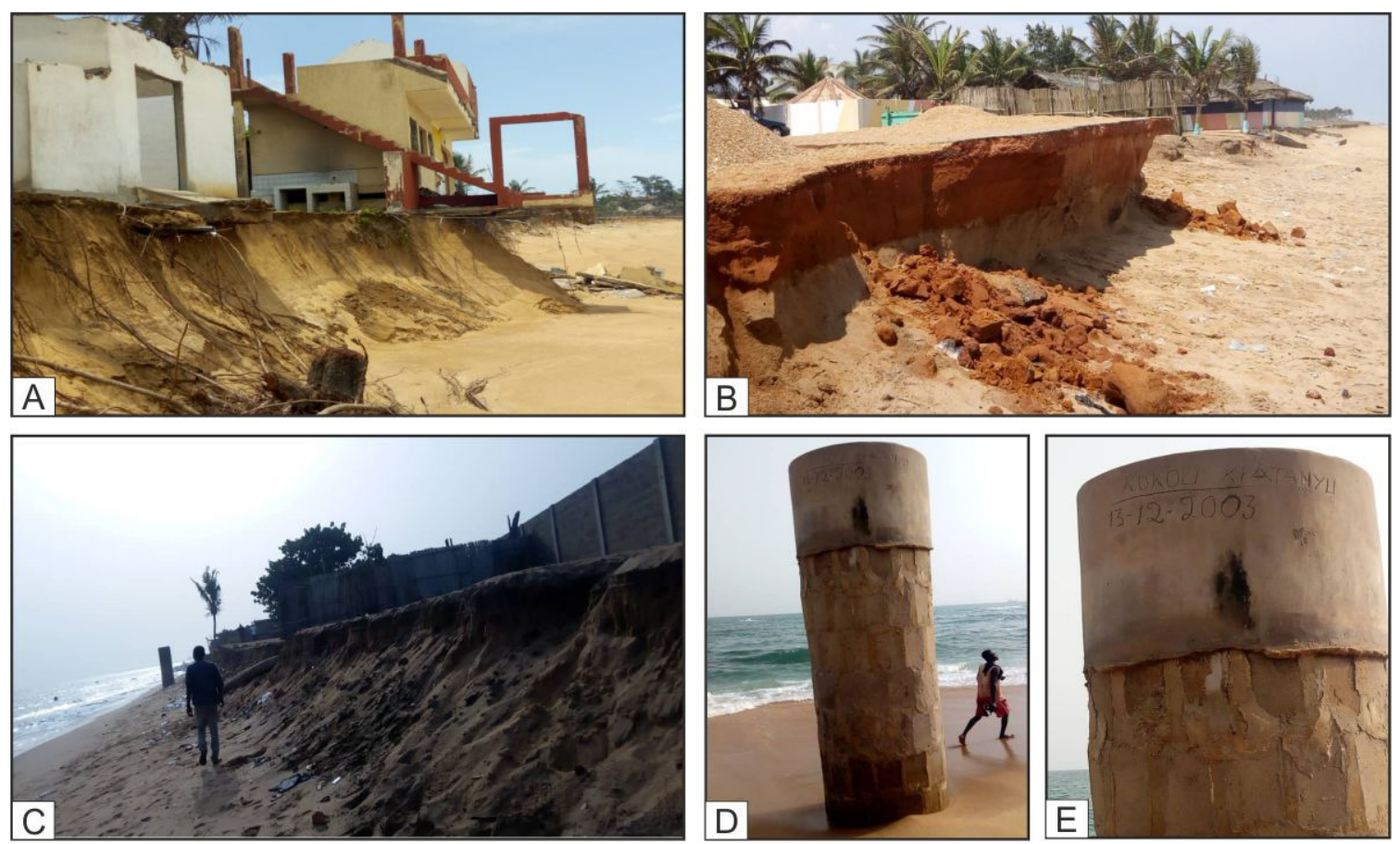

Figure 4. Significant examples (A-E) of the strong and active erosion processes along the eastern beach of Lomé (Photographs December 2019). 
The $46 \mathrm{~km}$ of the east coast of Togo are affected by sometimes strongly developed erosion processes, which result in a high removal rate of sediments and create very important and worrying management problems. The erosion results in a very marked coastal retreat (Figure 4) and development of current related erosional forms along the beaches located between the eastern part of Lomé and the Aného village. At present, the beach width is often restricted to between $4-10 \mathrm{~m}$ and the erosion is related to several causes, which result in different effects. As mentioned above, the most important cause of erosion is represented by the effects of the presence of the port structure on long shore currents. The erosion is not compensated by the long shore sediment transport, which is interrupted by the port, and so therefore there is not a sufficient clastic supply to the east of the port because of the lack of rivers with a significant amount of clastic material.

The erosion of the coast results from natural and anthropogenic concomitant factors such as: the reduction of the solid river supply mainly due to the presence of river dams; the direct wave action and coastal currents sediment transport; the subsidence and tectonic movements; the exploitation of underground water; and the wrong anthropic actions on land use and on the hydrographic network. Also, the construction of infrastructures, settlements and industrial structures and the immigration, etc. also favored erosion. A further negative phenomenon having non-secondary effects on beach nourishment is the use of river sand and gravel, and beach sandy deposits as construction materials. If neither reduced nor controlled, this material extraction will continue to cause in the future significant damages to various ecosystems, and more in general to the environment [29].

Some of the main processes that may affect the coast of Togo and neighboring areas are shown in Figure 5.

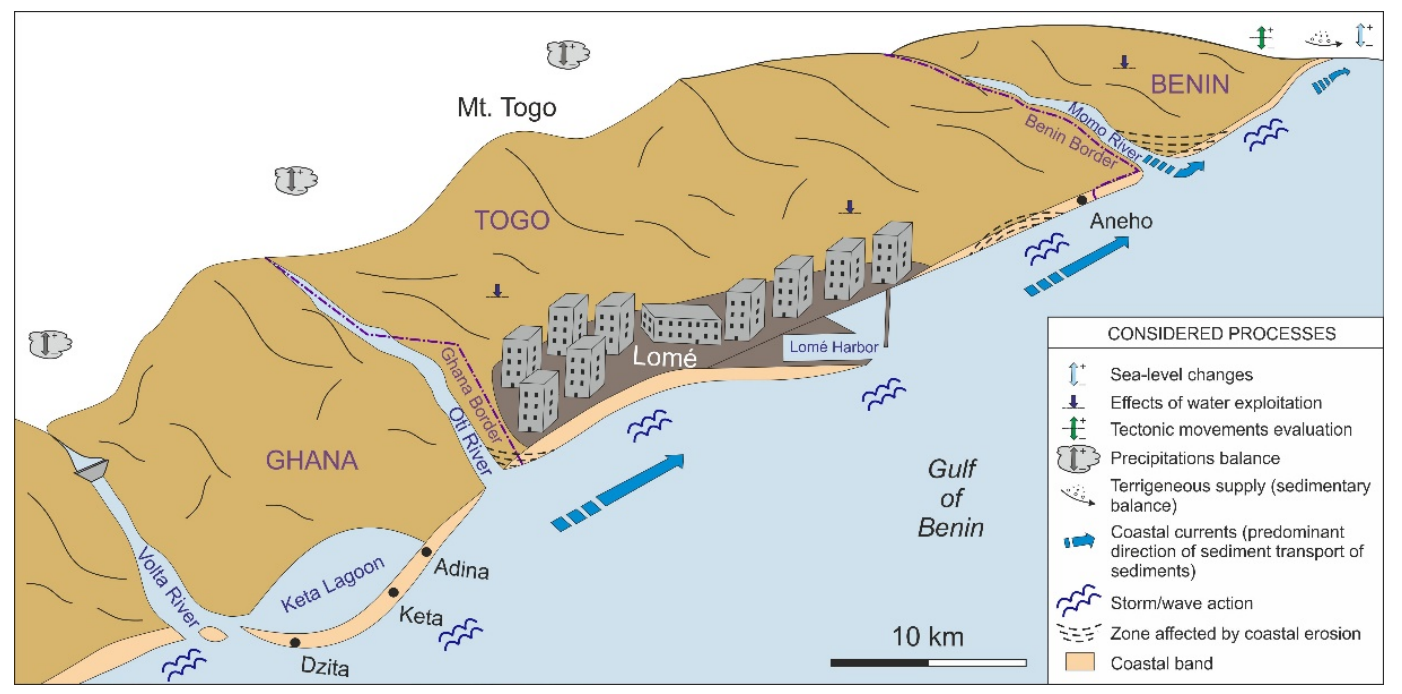

Figure 5. Sketch of the coastal strip studied (east Ghana-Togo-west Benin) with evidenced some processes that control the coastal evolution. Seaward-directed flows (not shown in Figure) may also occur to favor the onshore to offshore transport of sediments.

The coastal erosion results in a reduction of the beach and in the formation of a marked step in the internal part of the beach (Figure 6A-D). The erosion has also reached many trees, testifying to the loss of plant resources in the area, which on the east coast of Togo is worsened by urbanization processes, contrarily to what happens along to the west coast. In particular, the loss of coconut trees, which are a true resource of the coastal economy, caused enormous damage to the local people. 

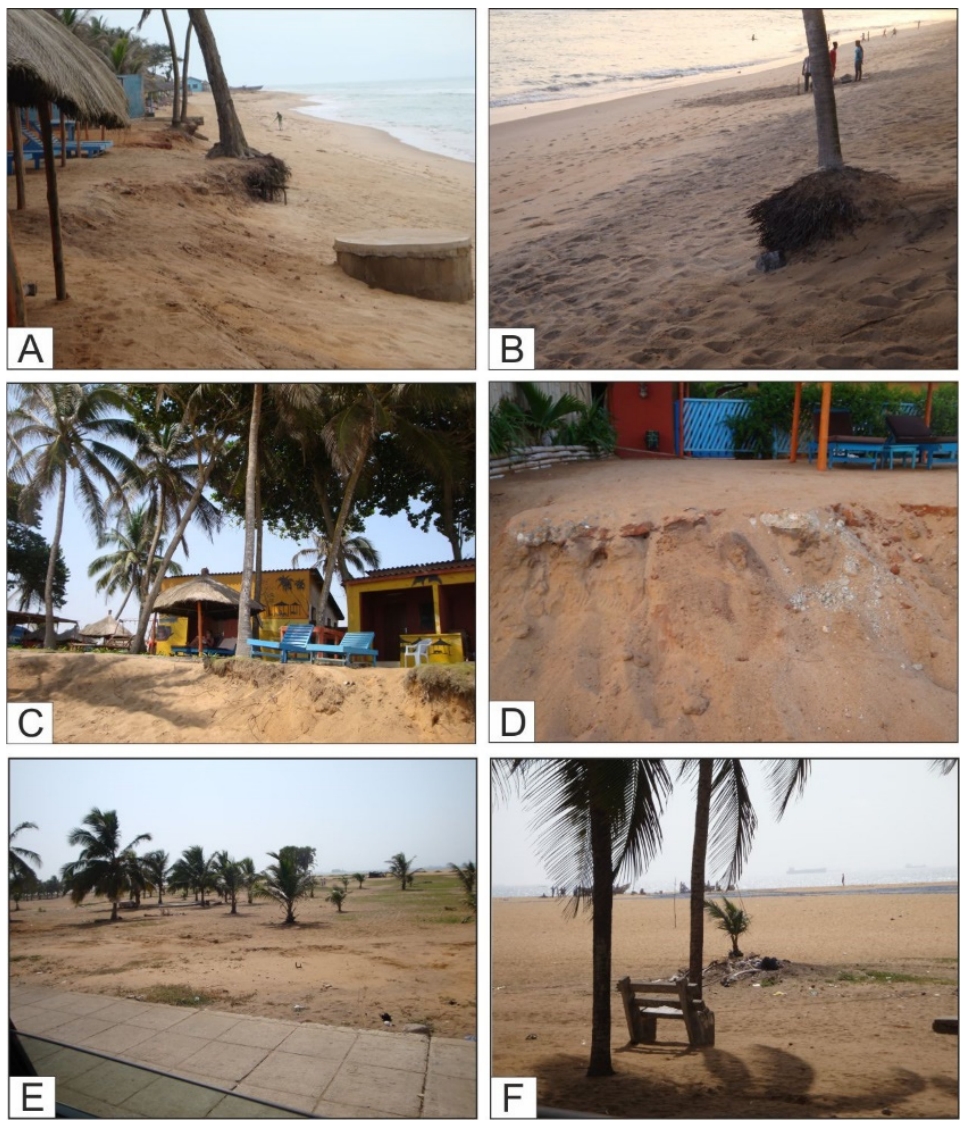

Figure 6. Geomorphological erosional and growth forms along the beaches of the coast of Togo. (A-D), erosional forms to the east of the port of Lomé; (E,F), expanding beaches (about $400 \mathrm{~m}$ wide) to the west of the port of Lomé. Field observations carried out in January 2018 and January 2020.

The reported values of longshore sediment transport [27], which is generally directed eastward, ranges between 0 and 1.2 million $\mathrm{m}^{3}$ /year, depending on the location. Other authors reported values of the same order (e.g., [30-33]). In all these studies, the estimation of the longshore sediment transport is based on simple empirical formulas or on measurements of shoreline variations near the major port breakwaters. Neither a full wave modelling nor a comprehensive sediment transport model for the entire study area were used in previous studies.

As regards the erosional processes affecting the area considered in the present study, the observed features allow for considering that the erosion of the beach is still very significant and destined to developed further, being favored by the presence of the easily erodible lithofacies that characterize the immediate hinterland.

The most significant example of the erosion is attested by the destruction and the partial disappearance of the beach rock previously connected to the beach and now dismembered in different zones toward Benin. Moreover, a well-developed and often continuous erosional step marks the internal part of the beach. According to some information, a straight relief occurring some tens of meters (up to about $140 \mathrm{~m}$ ) from the coast to the east of the Lomé port (Figure 7) should represent the result of the dismemberment of an old road (personal communication to F. Guerrera) of several decades ago. 

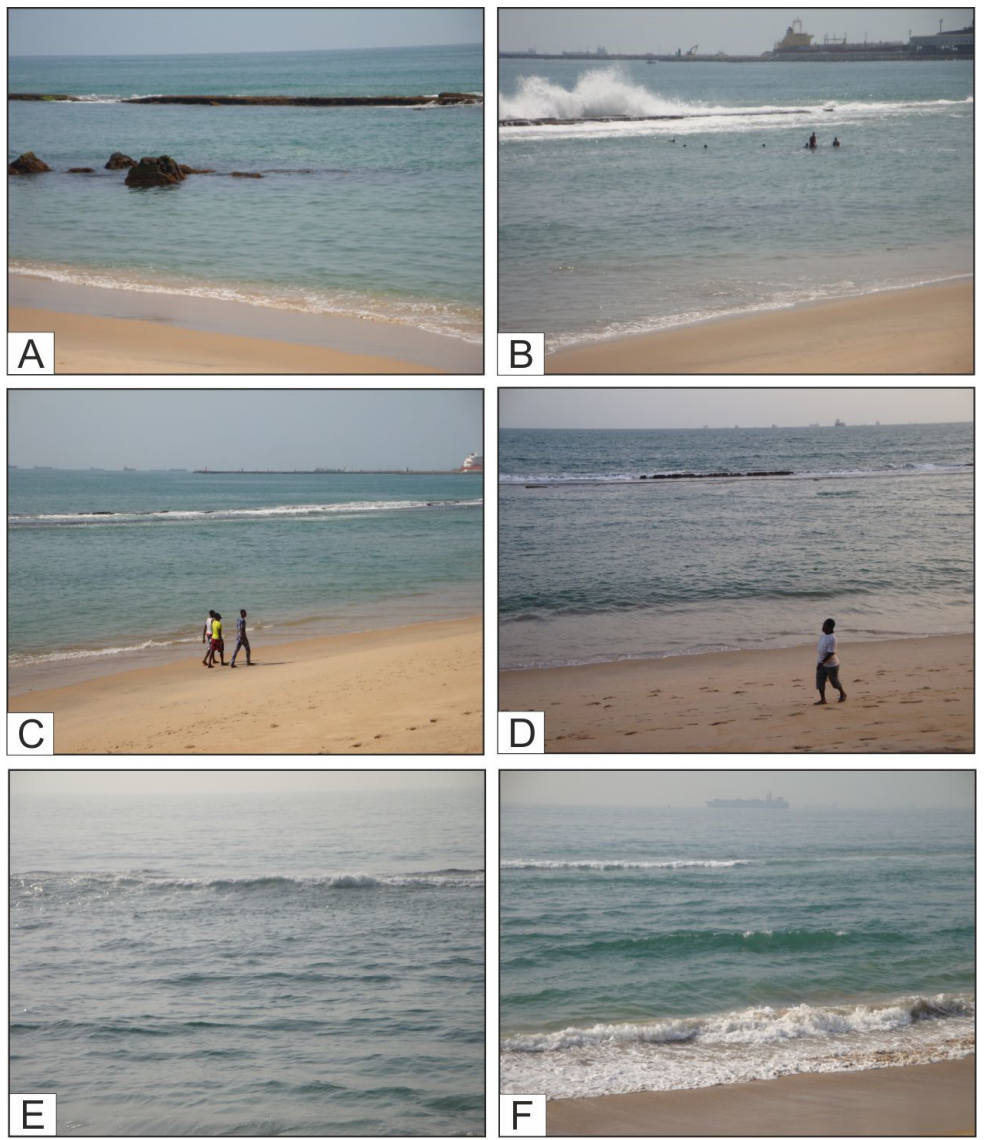

Figure 7. Submerged relief to the east of the port of Lomé, which emerges during the low tide as in (A-D) and disappears during the high tide (E,F). In (B) the eastern part of the port is visible. Observations carried out during the period 2014-2020 (photographs December 2019).

Observations carried out in the last six years (2014-2020) allowed for recognizing that the top of this relief emerges during the low tide and disappears during the high tide. Evaluations concerning the observable features allowed the recognition of some parametres, which are summarized in Figure 8.

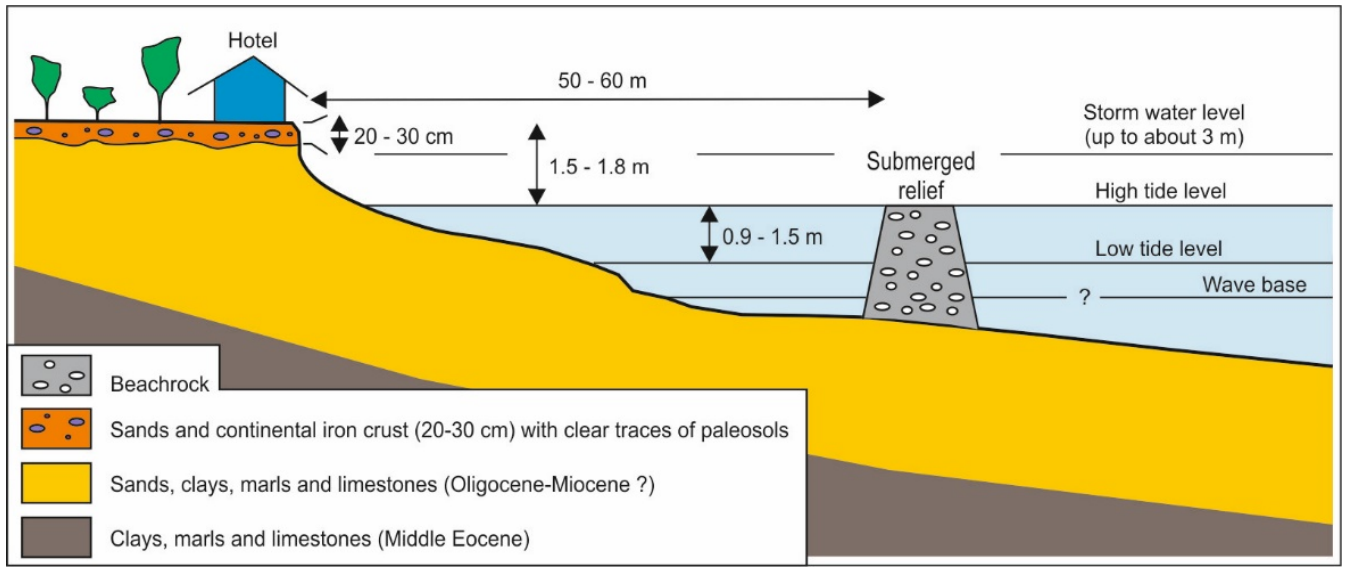

Figure 8. Geological and Geomorphological section across a sector of the beach of Lomè to the east of the port. The tidal excursion (observations carried out in December 2016 and December 2019) causes the emergence and submersion of the relief. The indicated value of storm water level is indicative. 


\subsection{Sediment Grain Size}

Several samples were collected to characterize the sediment grain size of the beaches located to the west and to the east of Lomé port. Based on the macroscopic evidence of grain-size homogeneity, only four sediment samples were analyzed, and in particular the samples collected from the swash zone (one sample) and from emerged beach (one sample), on both sites of the port. The results of grain-size analyses are shown in Table 1.

Table 1. Sediment grain size parameters of the samples collected in the Lomé beach.

\begin{tabular}{|c|c|c|c|c|c|c|c|c|c|}
\hline Sample & $\%$ Pelite & $\%$ Sand & $\%$ Gravel & Mode & Mean & $\begin{array}{c}\text { Sorting } \\
\text { Coefficient }\end{array}$ & $\begin{array}{l}\text { Coefficient } \\
\text { of Skewness }\end{array}$ & $\begin{array}{l}\text { Graphic } \\
\text { Kurtosis }\end{array}$ & Classification \\
\hline 1 (swash zone west of Lomè port) & 0.03 & 99.77 & 0.20 & 2.00 & 1.14 & 0.71 & -0.10 & 0.89 & sand \\
\hline 2 (emerged beach west of Lomè port) & 0.01 & 99.17 & 0.82 & 1.00 & 0.79 & 0.74 & 0.07 & 1.00 & sand \\
\hline 3 (swash zone east of Lomè port) & 0.01 & 98.95 & 1.04 & 1.00 & 0.87 & 0.73 & -0.02 & 0.90 & sand \\
\hline 4 (emerged beach east of Lomè port) & 0.03 & 99.69 & 0.28 & 2.00 & 1.06 & 0.69 & -0.17 & 0.79 & sand \\
\hline
\end{tabular}

Grain size was determined by wet sieving. After quartering, the samples were dried in an oven at $70-80^{\circ} \mathrm{C}$ for about $48 \mathrm{~h}$. Dry sediment samples were pre-treated with a $16 \%$ $\mathrm{H}_{2} \mathrm{O}_{2}$ solution to facilitate the separation of grains and remove the organic matter. Then, the separation of the coarser to finer fraction (pelite) was carried out by washing with water on a sieve with a mesh of $62.5 \mu \mathrm{m}$; the two fractions thus obtained were dried in an oven at $60-90{ }^{\circ} \mathrm{C}$ for about $48 \mathrm{~h}$. The coarse fraction $(>62.5 \mu \mathrm{m})$ was analyzed by sieving, using a pile of sieves (Series A.S.T.M.) arranged on each other from top to bottom with a decreasing mesh, which allowed for the separation of the different grain size classes according to the scale of Wentworth. The sediment was put into the first highest sieve and submitted to vibration for two cycles of $6 \mathrm{~min}$; the fraction retained by each single sieve was weighed and expressed in \% with respect to the total weight of the sample examined. The pelitic fraction and the gravel one resulted to be practically absent. The beach sediments are represented by sand. The maximum amount of gravel is $1.04 \%$ and the maximum pelite content is $0.03 \%$. Sands are mainly from coarse- to medium-grained. Sediments are unimodal (modal value from 1 to 2 ) on both sides of the Lomè port. Beach sediments to the west of the port show a mean ranging from 1.14 to 0.79 and the sorting from 0.71 to 0.74 . The asymmetry value is from -0.10 to 0.07 . To the east of the port the mean ranges from 0.87 to 1.06 and the sorting varies from 0.73 to 0.69 . Asymmetry is from -0.02 to -0.17 . The value of kurtosis resulted to be ranging from 0.89 to 1.00 to the west of the port and from 0.79 to 0.90 to the east.

Sediments show a moderate sorting on both considered beaches and significant differences are not even recognizable between the samples from swash zone and from emerged beach. A slight difference emerges for the frequency distribution, which appears to be platicurtic in the beach to the east of the port compared to the mesocurtic one of the sediments to the west, the latter showing a slightly better sorting.

\section{Discussion}

The main causes of the ongoing erosional processes have been distinguished into natural and anthropogenic causes. The effects result from the combination of both types. The quantitative evaluation of the influence of each cause is difficult, not having adequate instrumental data and monitoring networks. For this reason the prevalence of one or the other cause is based on the relevance of the related effect and on the environmental impact. Future coastal investigations will be necessary, aiming to collect quantitative data for a more complete interpretation.

The erosion and the consequent disappearance of entire coastal stretches derives from processes whose effects act on very different dimensional and temporal scales. 


\subsection{Natural Causes and Effects}

The main natural causes and effects of the coastal erosion are considered in this section. However, a quantitative evaluation of processes in not possible because specific available data are not sufficient, which underlines the need to activate targeted research activities. In general, the main causes of the coastal erosion are as follows.

1. Geological vulnerability. The prevalent sandy incoherent lithofacies and beach sediments of the coastal strip are easily ongoing to erosion processes, also because they are not protected sufficiently by vegetation. Moreover, the coastal area is characterized by a gentle topographical profile, which favors erosive processes together with the occurrence of lagoons.

2. Tectonics and subsidence. The tectonic system that characterizes the Bight of Benin (land and sea area) consists of extensional faults that caused the lowering of crustal blocks, also favored probably by a generalized isostatic epeirogenic subsidence. However, the validation and evaluation of these movements in not possible for the lack of instrumental monitoring. These processes and the sediment compaction related to the exploitation of water reflect on relative sea level variations, adding a component of sea level rise.

3. Oceanographic variations. Oceanographic conditions changed over time. Some qualitative estimate of processes indicates an irregular evolutionary trend characterized by the increase of the coastal currents, and storm surges. Instead, the prevailing direction of the longshore currents remained constantly from west to east.

4. Hydrographic network. The low "relief energy" marked by the gentle shape of reliefs and the very low fluvial incision results into the scarce clastic contributions for the beach nourishment.

5. Climate and sea level changes. The general conditions indicate a progressive global warming as the cause of a possible climate change, which probably will result into sea level rise, heavy and prolonged rainfall, and marked flood erosion. The sea level rise will also cause the increase of the wave set up effects along the coast.

In summary, the geological data point out a vulnerability of the Togo margin related to the prevalence of incoherent lithofacies and to vertical movements that can result in lowering the soil. A geomorphological fragility of the coastal area also occurs, related to a beach profile with a low angle of dip, which favor the extension of the wave set up. Moreover, the local poorly developed hydrographic network brings only a reduced amount of clastic contribution for beach nourishment. In addition, the direct wave action (shoaling), and related strong coastal currents, the tide excursion and tidal currents cause erosion. The quantitative evaluation of relationships between sedimentation and erosion would require instrumental monitoring, at present not available. Finally, it is necessary to pay attention to the possible future relative sea level rise that could become the dominant cause of erosion in Bight of Benin, also amplifying the effects of other processes.

The intensity of erosional processes is however variable in the different sectors of the study area. In fact, some coastal segments disappear more quickly than other ones such as for example the historically well-known villages of the Aného area.

\subsection{Anthropic Causes and Effects}

Different anthropic factors that cause negative effects on the considered coastal strip are reported and in particular those having the greatest influence on erosion phenomena.

1. Construction of the port of Lomé. This great commercial structure, which reaches a great depth, has an important environmental impact, so as to alter the natural flow of coastal marine currents and the natural distribution of sediments. The port and associated infrastructures underwent the following several transformations between 2009 and 2015 (Source: Google Earth), which significantly developed since 2010: (i) construction of a pier perpendicular to the main breakwater of the port, and (ii) realization of a third pier and associated container park. Its western jetty (1200 m 
long) hinders the west to east moving longshore drift and related sediment transport and causes sand accumulation on the beach located to the west of the port and induces a sediment deficit down-drift to the structure and a strong erosion on the coast to the east of the port ([34]; among others). The main effect translates into the dramatic erosion of the eastern coast, which results in a marked retreat rate, in some zones amounting to up to about $10 \mathrm{~m} /$ year in the last 6 years. In addition, the erosion affected several hundred hectares of coconut fields, and threatened some infrastructures, such as roads, the phosphate factory and the town of Aneho ([34]; among others).

2. Migration and urbanization. A massive uncontrolled migration toward the coast of Togo (Banguida, Agouényivé and Adidogomé; suburbs of Lomé) caused socioenvironmental problems due to the lack of infrastructures. The main immediate effect of this process was the soil consumption: cementation, felling of forests and natural plant systems, destruction of coastal dunes, etc. Furthermore, the intensive exploitation of the surface aquifer in the unconsolidated sedimentary cover induced subsidence that may favors the marine ingression.

3. Exploitation of sand and gravel. The use of unconsolidated materials is a very widespread practice in Togo, exploiting sandy outcrops wherever present, and in particular from rivers and beaches. Removal of these materials utilized as construction aggregates caused a significant damage to the different ecosystems involved. In fact, this uncontrolled use produced a general environmental degradation and a negative sedimentary balance between materials transported to the coast and sediments removed. Ayenagbo et al. [29] proposed a method to control and regulate this process in Togo.

4. Modifications of the hydrographic network. From the examination of the longitudinal profiles of the main water courses/water ways, there are no indications of significant tectonic and/or epeirogenetic movements. Therefore, the main modifications mainly result from the following anthropic actions carried out along the rivers: construction and management of dams; indiscriminate extraction of materials; modifications of river segments; etc. These actions modified the amount of river sediment supply, resulting in a reduction of the clastic contribution to the sea.

5. Impact of urban structures. The realization of airport, industries, roads, crowded neighborhoods, large hotels, etc., and of the port of Lomè, resulted into a certain environmental impact.

In summary, the strong migrations of population towards the coastal strip (hinterland of Lomé) created new settlements with ever-increasing needs and caused a significant environmental impact (e.g., oversized land use). Anthropic structures realized along the coast altered natural processes, triggering both degradation and instability, and the wild exploitation of subsoil water induced subsidence. More in general, the anthropic activity involving an incorrect soil use resulted in many negative effects acting at different levels on ecosystems and triggering a natural reaction to restore the lost equilibrium by means the activation of processes, sometimes leading to significant economic losses (and in some cases human).

The structure with the most important impact on coastal erosion is the port of Lomé that constitutes a major maritime facility in West Africa, also for the marine traffic of container ships. This structure, which acts directly on the coastal wave induced currents, modified the coastal dynamics and related sediment distribution, triggering deposition along the coast at the west of the port (Figures 3 and 6) and marked erosion on the east (Figures 4 and 6). In other words, the structure controls the beach evolution, causing opposite trends marked by beach progradation and mainly beach recession on the different sides of the port. The average erosional rate for the last 40 years in some sectors of the area to the east of the port of Lomè is about $5 \mathrm{~m}$ /year. A similar value has been found in the coastline adjacent to Lake Togo [35]. Analyses of Satellite images collected from 1986 to 2020 (Landsat 4, 5 and 8) pointed out in the last years a marked acceleration of 
the coastal retreat to the east of the port. In particular, for the period 2014-2020 the sector characterized by the major erosion, which is located about $0.5 \mathrm{~km}$ from the eastern pear, shows a retreat rate of about $10 \mathrm{~m} /$ year.

Other anthropic structures (roads, large buildings, etc.) acted on the natural sedimentary balance when causing modifications to morphological profiles and related loss of sediments (e.g., dismantling of dunal systems). Structures close to the east coast are threatened by the erosion development.

The authors are aware that the proposed study was based on incomplete and data still in progress. This is especially due to the intrinsic difficulties encountered when operating in developing countries where the background of instrumental data is poor or non-existent. However, considering the macroscopic entity of the observed phenomena and, above all, of the severity of the resulting socio-economic and environmental impacts, it was preferred that we publish the data collected so far.

\section{Management Proposals}

The vulnerability to erosion recognized in the study area must be faced at two different levels: (1) to buffer critical situations by means of emergency technical interventions and to develop successive actions aiming to plan the realization of protection works in the context of a general long-term program; (2) to create an interdisciplinary scientific organization and working groups with the participation of different countries of the Bight of Benin and scientists from other countries, with the aim to carry out accurate quantitative studies concerning the considered coastal zone and the above described subjects and problems, also through monitoring activity.

\subsection{Indications of Possible Technical Interventions}

During the realization of protection works, attention to safeguarding the natural environment must be paid. However, the choice of the works to realize must be carried out only after a careful analysis of the entire beach system features and dynamics, considering also the possible future sea level change. In fact, the expected future relative sea level rise will imply political, economic and technical choices, which are difficult to evaluate at present.

The following protection works may be preliminarily considered.

1. Realization of protection breakwaters along the shoreline, to cope with the urgency to intervene and to stop the erosion. However it is necessary to evaluate the effects of these works on the local dynamics. Considering the experience and technical information acquired for the construction of the port of Lomè, it could be appropriate to realize piers and / or groins (once the physical and dynamic features of a certain data are studied). In particular, in order to stem the current erosion affecting the area adjacent to the east pier, an expansion of the port structure can be foreseen, but carefully considering in the project the further possible future erosion effects induced on the down-drift side and related mitigation actions. This choice would have also a significant positive economic impact.

Because the study area is characterized by E-W flowing longshore currents, groins built perpendicular to the coast should be useful to trap the sand, blocking erosion by promoting nourishment. In fact, these structures act on longshore currents, decreasing their speed and involving sediment deposition. However, erosional processes may develop also on down-drift side of groins. To avoid erosion it is necessary to elaborate projects based on sufficient and validated scientific data, which allow adopting consequent appropriated technical solutions, providing for example to the realization of groin fields. Without an adequate supply of sediments, groins have a limited value as protection work. Therefore, the possibility to use these transversal defense works together with submerged breakwaters and artificial sediment supply to realize protected artificial nourishments could be evaluated.

2. In areas of greatest erosion, particularly useful coastal defense works could be revetments or seawalls (the latter only when strictly necessary). The construction of 
suitably sized offshore submerged breakwaters may be also evaluated, with the aim to mitigate the wave energy, favoring sedimentation processes.

3. Other traditional protection works providing for the reduction of wave, current and wind energy may be realized and non-conventional structures may be considered. In any case, it is, however, important to point out once again that works must be realized after accurate studies. It is also necessary that the realization of protection structures be followed by a careful monitoring of their effects on coastal dynamics, on the seabed and shoreline position.

\subsection{Planning for Interdisciplinary Studies}

Continuing suggestions of the above-mentioned, any realization of protection works must be preceded by investigation on the historical and recent evolution of the area. Moreover, it is necessary to define the local dynamics. Therefore, data on wind regime, wave climate and tide values are required. It is important also to collect information about the historical evolution of the coast, to evaluate shoreline changes, to estimate the river sediment supply and to define possible interferences of anthropic works (port, protection works, etc.) with the coastal transport of sediments. All collected data may give information about the main factors that control the coastal evolution.

Therefore, suggested basic investigations and surveys (among others) over a significant period of a several years as needed, may be as follows:

1. Coastal monitoring with appropriately located facilities and instruments;

2. Study and analysis of historical and recent shoreline variations and beach width changes;

3. Bathymetric reconstruction of the submarine beach and variation analyses;

4. Sediment grain-size analyses, sediment movements and sedimentary balance;

5. Tides, wind, wave and current analyses to reconstruct the local hydrodynamics;

6. Evaluation of the influence of anthropic structures on coastal dynamics;

7. Soil movement evaluation;

8. Realization of a multi-thematic cartography of the coast, to update periodically.

The main subject that must be considered are the geological, geomorphological, sedimentological, and oceanographic features, soil use (mainly occupation and exploitation), and social and industrial activities, etc. The continuous updating of these parameters (and related maps) allows for a scientific control of the coastal evolution and of the related vulnerability, in favor of the safeguard of natural spaces and marine resources.

Certainly, the different types of analysis are interrelated and it is not possible to summarize here all the necessary data and instruments. However, in order to have a real control of the coastal evolution, scientifically qualified structures equipped with modern instruments and adequate personnel are necessary. Thus, quantitative values that are necessary for interdisciplinary analysis of coastal processes would be available.

This objective may be reached through the collaboration between all countries of the Bight of Benin grouped into an operative international structure under the common responsibility of Ghana, Togo and Benin governments. This collaboration would determine important results for the entire Bight of Benin coastal zone because the collected data and the evolutionary models reconstructed might be used also for comparison with coastal sectors of other regions. Moreover, a shared planning of protection interventions and a more correct management of the coastal zone would be allowed.

\section{Discussion and Conclusions}

The progressive strong erosion recognized in different coastal stretches of the Bight of Benin results from the interference of natural and anthropic causes. The action induced by the different processes is not homogeneous and their dimensional evaluation currently is not easily determinable, given the absence of specific instrumental networks.

In the considered area, the study allowed for identifying four different coastal sectors (Figure 9) characterized by a different evolution. 


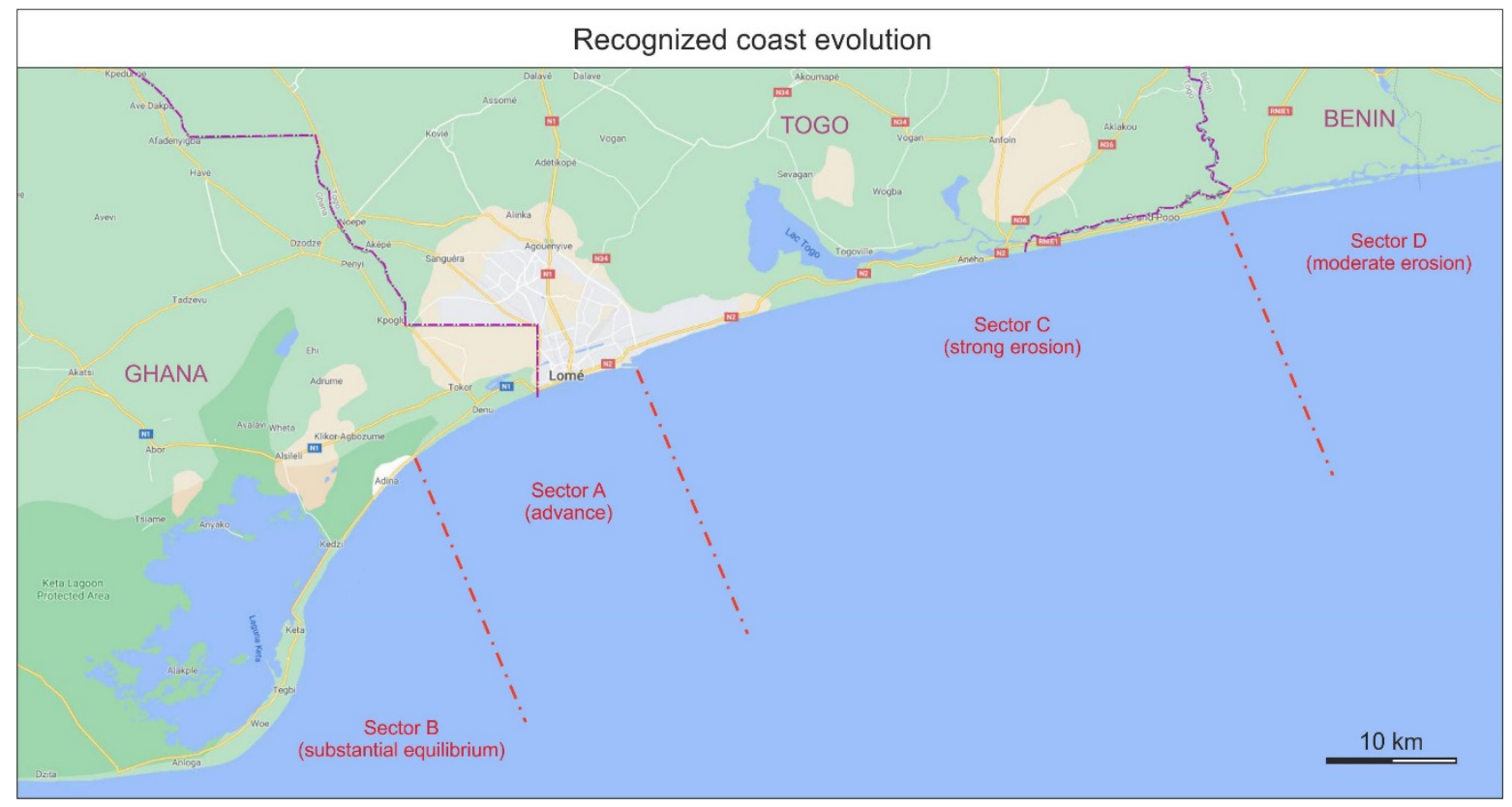

Figure 9. Different evolutionary trends (equilibrium, advance, erosion) of coastal sectors of Ghana, Togo and Benin.

Sector A. This area is at present characterized by a beach advance. The main example are the beaches located to the west of the port of Lomé and in east Ghana.

Sector B. This sector shows at present a substantial equilibrium. A representative example of this stability is the Volta river delta (Ghana), even if this feature is experiencing localized erosion in some zones, especially in the localities Dzita, Keta and Adina. The significant reduction of the river clastic supply caused by the realization of the Akosombo dam (Volta River) resulted in poor coastal nourishment, preventing the coastal advance.

Sector $C$. This area is very vulnerable and affected by strong erosion. Striking examples are observable in the coastal stretch located between the east pier of the port of Lomé and Aného, where in some sectors an erosion rate of at least about $130 \mathrm{~m}$ in the last 40 years has been estimated. In particular, the erosion is clearly still active (with a varying amount) between the port and the "Mineral Wharf" of Kpémé, which represents one of the main installations of the "New Phosphate Company" in Togo.

A similar erosion affects other minor sites of western Benin and eastern Ghana.

Sector D. This area shows moderate erosion even if the situation is constantly evolving. This coastal sector is characterized by reduced and small beaches that are sometimes recognizable to the east of the described Sector $C$ and in the western part of Benin.

\section{Status of Ongoing Processes}

The coast of Togo, and the part of Ghana and Benin one that are located at the country borders with Togo are affected by strong erosional processes causing coastal retreats and loss of territory. This great problem is particularly important regarding consequences in areas with a high population density (e.g., eastern sector of Lomé) where the negative effects imply the need of interdisciplinary investigations aimed to characterize the phenomenon, and therefore to realize appropriate actions and protection works. The alternative to this approach is to consider that in the near future it will probably be necessary to transfer infrastructures and inhabited centers to more internal areas.

The impact of erosion on coastal infrastructure is evident and sometimes dramatic: (i) the removal of coastal sectors; (ii) thecontinuous problems involving readjustments of the socio-economic contexts; (iii) the consistent and continuous loss of productive coastal soil and problems for fishing and tourism; (iv) the progressive salinization of surface waters, groundwater and freshwater wells. 
The erosion processes have led over time to the loss of kilometers of roads of Togo, and more in general along the Abidjan-Lagos corridor, which is currently at times more threatened than ever. The involvement of houses of coastal settlements in the erosional phenomenon causes risks and induces the displacement of population who have to move inland, also losing the previous economic activities related to fishing. People resettle and activate new economic activities, which are not easy to carry out. For example, a major erosive event in August 2012 moved fifteen families to Doèvi Kopé and Agbavi.

As described above, some anthropogenic processes, which amplified the effects of natural ones, have strongly controlled the recent evolution of the studied area. Up to now, the influence of climatic factors seems to be less relevant with respect other processes induced by human activity. However, the climate change could be of fundamental importance in controlling the evolution of the coastal strip in the near future.

Some estimations about the relative sea level change indicate that considered 1930 as the reference year, the sea level rise in the Bight of Benin could reach $30 \mathrm{~cm}$ in the year 2030 [36]. In particular, the climate scenario, with respect to the average scenario of greenhouse gas emissions 1S92a (IPCC reference), foresees in 2030 a progressive increase up to $0.5^{\circ} \mathrm{C}$ of the average estimated temperature. Rates of sea level rise between $3-23 \mathrm{~cm}$ in $2030,7.5-38 \mathrm{~cm}$ in 2050 , and $20-86 \mathrm{~cm}$ in 2010 were calculated [36]. Higher values were obtained for different scenarios. More recent data [37] indicate values of sea level rise for a basic scenario and for an extreme one ranging between 7 and $39 \mathrm{~cm}$ for 2050 and 20 and $59 \mathrm{~cm}$ for 2100. Values from the average scenario are $20 \mathrm{~cm}$ for the year 2050 and $49 \mathrm{~cm}$ for the year 2100. The climate change also increases the exposure of the coastal area to erosion. Other studies indicate an average recession in the last decades of the Togo shoreline near the Togo Lake ranging from 1.66 to $5.25 \mathrm{~m} /$ year [35]. The erosion is related to the increase of high marine energy events or bad weather (e.g., storms, hurricanes, heavy rains, etc.). The consequences on progressive soil loss are increasingly alarming.

In the context of this general framework, the relative sea level rise must be considered as a generalized negative background noise, which can be strengthened through the combination with other natural or anthropic factors.

Concerning the four sectors A, B, C and D recognized in the studied coastal strip (see above the first part of the Section 7) the types $C$ and $D$ are the most represented ones, and they have long alarmed the authorities and population. The main causes of erosion have been already described. In particular, the most important factor in the Lomé area is the construction of the port, which changed the local hydrodynamics.

In general, the examined coast currently shows two main geomorphological systems characterized by different evolutionary trends. The first system includes the sectors A and $\mathrm{B}$, corresponding to the west coast of Togo (about $10 \mathrm{~km}$ long) and the adjacent stretch of the Ghana coast (about $40 \mathrm{~km}$ long), which show a consistent growth or by a substantial equilibrium, respectively. The second one corresponds to the sectors $C$ and $D$ and comprises the east coast of Togo (about $46 \mathrm{~km}$ long) and the adjacent west coast of Benin (40 km long), which are affected by moderate to more often severe erosional processes, or by generally moderate erosional processes, respectively.

Sedimentation or erosion prevail in the two different geomorphological subsystems but the rate of the processes is neither homogeneous nor constant, because local factors, which are difficult to estimate individually.

However, in particular, the coastal areas located to the east of the port of Lomé represent "areas at risk", due to the strong coastal erosion that has been going on for a long time. The effects of the coastal erosion causes a series of significant and progressive socio-economic damages to which is increasingly difficult to remedy. It is therefore evident that Togo must develop urgent actions to mitigate the problem, finding effective solutions to be included in the 2018-2022 National Development Plan.

Author Contributions: All the authors contributed to the different parts of the article. All authors have read and agreed to the published version of the manuscript. 
Funding: Research supported by University of Urbino Carlo Bo (funds Ricerca Scientifica 2020, DiSPeA-M. Tramontana); Research Project CGL2016-75679-P, Spanish Ministry of Education and Science; Research Groups, Projects of the Generalitat Valenciana, Alicante University (CTMA-IGA).

Institutional Review Board Statement: Not applicable.

Informed Consent Statement: Not applicable.

Data Availability Statement: Data is contained within the article.

Acknowledgments: We are indebted to Claudia Patamia and Paolo Faberi, of the "Volontariato Internazionale Laico Sostegno Emarginati" /VILSE (www.vilse.it), for their useful help in observations, during many missions in Togo. Authors also wish to acknowledge five anonymous reviewers for useful comments and suggestions.

Conflicts of Interest: The authors declare no conflict of interest.

\section{References}

1. Blivi, A.B.; Adjoussi, P. Erosion des Cotes Togolaises: Effet Antropique. Rapport Interne. Présenté Par A.A. Egbare (Directeur Général Météo-Togo). 2004. Available online: http:/ / www.wamis.org/agm/meetings/iwacc09/S3-Abi-Egbare.pdf (accessed on 19 May 2020).

2. Spekker, H.; Ammermann, K.; Guillart, D.; Lankenau, D. Küstenschutzmaßnahmen in Togo-Stabilisierung erosionsgefährdeter Strandabschnitte und Schutz des Containerterminals Lomé durch den Neubau einer Buhne. Bautechnik 2010, 87, $311-317$. [CrossRef]

3. Blivi, A. Quelques aspects du beach-rock dans le golfe du Bénin: Le cas du Togo. Rev. CAMES Série B 1998, 10, 43-56.

4. Banito, A.; Verdier, V.; Essotina Kpémoua, K.; Wydra, K. Assessment of major cassava diseases in Togo in relation to agronomic and environmental characteristics in a systems approach. Afr. J. Agric. Res. 2007, 9, 418-428.

5. Kaki, C.; Laibi, R.A.; Oyede, L.M. Evolution of Beninese coastline from 1963 to 2005: Causes and consequences. Br. J. Environ. Clim. Chang. 2011, 1, 216-231. [CrossRef]

6. Rutten, G.L. Interactions between Beachrock Formations and Shoreline Evolution. Case Study: Togo. Master's Thesis, Delft University of Technology, Delft, The Netherlands, 2011.

7. Fiagan, K.A. L'impact de l'érosion côtière sur la pêche artisanale maritime au Togo. Rev. Géogr. Trop. Environ. 2013, 2, 1-13.

8. Laibi, R.A.; Anthony, E.J.; Almar, R.; Castelle, B.; Senechal, N.; Kestenare, E. Longshore drift cell development on the humanimpacted Bight of Benin sand barrier coast, West Africa. J. Coast. Res. 2014, 70, 78-83. [CrossRef]

9. Melet, A.; Almar, R.; Meyssignac, B. What dominates sea level at the coast: A case study for the Gulf of Guinea. Ocean Dyn. 2016, 66, 623-636. [CrossRef]

10. Ozer, P.; Hountondji, Y.-C.; De Longueville, F. Evolution Récente du Trait de Côte Dans le Golfe du Bénin. Exemples du Togo et du Bénin. 2017. Available online: https:/ / www.researchgate.net/publication/323475663 (accessed on 19 May 2020).

11. Anthony, E.J.; Almar, R.; Besset, M.; Reyns, J.; Laibi, R.; Ranasinghe, R.; Abessolo Ondoa, G.; Vacchi, M. Response of the Bight of Benin (Gulf of Guinea, West Africa) coastline to anthropogenic and natural forcing, Part 2: Sources and patterns of sediment supply, sediment cells, and recent shoreline variations. Cont. Shelf Res. 2019, 173, 93-103. [CrossRef]

12. Abessolo, O.G.; Larson, M.; Almar, R.; Castelle, B.; Anthony, E.J.; Reyns, J. Modeling regional coastal evolution in the Bight of Benin, Gulf of Guinea, West Africa. Conf. Pap. 2019. [CrossRef]

13. Syvitski, J.P.; Vörösmarty, C.J.; Kettner, A.J.; Green, P. Impact of humans on the flux of terrestrial sediment to the global coastal ocean. Science 2005, 308, 376-380. [CrossRef]

14. Syvitski, J.P.; Saito, Y. Morphodynamics of deltas under the influence of humans. Glob. Planet. Chang. 2007, 57, 261-282. [CrossRef]

15. Syvitski, J.P.; Kettner, A.J.; Overeem, I.; Hutton, E.W.; Hannon, M.T.; Brakenridge, G.R.; Day, J.; Vörösmarty, C.; Saito, Y.; Giosan, L.; et al. Sinking deltas due to human activities. Nat. Geosci. 2009, 2, 681-686. [CrossRef]

16. Anthony, E.J.; Marriner, N.; Morhange, C. Human influence and the changing geomorphology of Mediterranean deltas and coasts over the last 6000 years: From progradation to destruction phase? Earth-Sci. Rev. 2014, 139, 336-361. [CrossRef]

17. Anthony, E.J. Wave influence in the construction, shaping and destruction of river deltas: A review. Mar. Geol. 2015, 361, 53-78. [CrossRef]

18. Bergillos, R.J.; Rodríguez-Delgado, C.; Millares, A.; Ortega-Sánchez, M.; Losada, M.A. Impact of river regulation on a Mediterranean delta: Assessment of managed versus unmanaged scenarios. Water Resour. Res. 2016, 52, 5132-5148. [CrossRef]

19. Bergillos, R.J.; López-Ruiz, A.; Ortega-Sánchez, M.; Masselink, G.; Losada, M.A. Implications of delta retreat on wave propagation and longshore sediment transport-Guadalfeo case study (southern Spain). Mar. Geol. 2016, 382, 1-16. [CrossRef]

20. Bergillos, R.J.; Ortega-Sánchez, M. Assessing and mitigating the landscape effects of river damming on the Guadalfeo River delta, southern Spain. Landsc. Urban Plan. 2017, 165, 117-129. [CrossRef]

21. Boateng, I. An application of GIS and coastal geomorphology for large scale assessment of coastal erosion and management: A case study of Ghana. J. Coast. Conserv. 2012, 16, 383-397. [CrossRef] 
22. Blivi, A.; Anthony, E.J.; Oyédé, L.M. Sand barrier development in the bight of Benin, West Africa. Ocean Coast. Manag. 2002, 45, 185-200. [CrossRef]

23. Sylvain, J.P.; Aregba, A.; Collart, J.; Godonou, K.S. Carte Géologique du Togo à 1/500.000 et Notice Explicative. République Togolaise, Direction Générale des Mines, de la Géologie et du Bureau National de Recherches Minières. Memoire 1986, 6, 120.

24. Guiraud, R. Tectonique, séismicité et volcanisme de la plaque africaine depuis le Méso-Cénozoique. In Proceedings of the Dakar Symposium Changments Globaux, 21-28 April 1986; pp. 179-182. Available online: http:/ / www.sudoc.abes.fr/cbs/DB=2.1/ /SRCH?IKT=12\&TRM=185126030\&COOKIE=U10178,Klecteurweb,D2.1,E0ec1e583-14,I250,B341720009+,SY,QDEF,A\%5C900 8+1, J,H2-26, 29, ,34, 39, ,44, 49-50,,53-78, ,80-87,NLECTEUR+PSI,R116.211.58.188,FN (accessed on 19 May 2020).

25. Mascle, J. Le golfe de Guinée (Atlantique Sud): Un exemple d'évolution des marges atlantiques en cisaillement. Mém. Soc. Géol. Fr. 1977, 128, 15-36.

26. Caunt, J. Ghana, L'erosione Della Costa che Distrugge Vite e Villaggi. Voci Globali 2016. Available online: https://vociglobali.it/ 2016/12/05/ghana-lerosione-della-costa-che-distrugge-vite-e-villaggi/ (accessed on 29 March 2018).

27. Allersma, E.; Tilmans, W.M.K. Coastal conditions in West Africa-A review. J. Ocean Coast. Manag. 1993, 19, 199-240. [CrossRef]

28. Giardino, A.; Schrijvershof, R.; Nederhoff, C.M.; de Vroeg, H.; Brière, C.; Tonnon, P.-K.; Caires, S.; Walstra, D.J.; Sosa, J.; van Verseveld, W.; et al. A quantitative assessment of human interventions and climate change on the West African sediment budget. Ocean Coast. Manag. 2018, 156, 249-265. [CrossRef]

29. Ayenagbo, K.; Kimatu, J.N.; Gondwe, J.; Rongcheng, W. The transportation and marketing implications of sand and gravel and its environmental impact in Lome-Togo. J. Econ. Int. Financ. 2011, 3, 125-138.

30. Tilmans, W.M.K.; de Vroeg, H.H.; Leclerc, J.-P. Coastal protection at Cotonou, Benin. In Proceedings of the International Conference on Coastal and Port Engineering in Developing Countries, Rio de Janeiro, Brazil, 25-29 September 1995; Volume 1, pp. 171-184.

31. Anthony, E.J. Beach-ridge progradation in response to sediment supply: Examples from West Africa. J. Mar. Geol. 1995, 129, 175-186. [CrossRef]

32. Anthony, E.J.; Blivi, A.B. Morphosedimentary evolution of a delta- sourced, drift aligned sand barrier-lagoon complex, western Bight of Benin. Mar. Geol. 1999, 158, 161-176. [CrossRef]

33. Almar, R.; Kestenare, E.; Reyns, J.; Jouanno, J.; Anthony, E.J.; Laibi, R.; Hemer, M.; Du Penhoat, Y.; Ranasinghe, R. Response of the Bight of Benin (Gulf of Guinea, West Africa) coastline to anthropogenic and natural forcing. Part 1: Wave Climate variability and impacts on the longshore sediment transport. J. Cont. Shelf Res. 2015, 110, 48-59. [CrossRef]

34. Blivi, A. Morphology and current dynamics of the coast of Togo. Geo-Eco-Trop 1993, 17, 21-35.

35. Konko, Y.; Bagaram, B.; Julien, F.; Akpamou, K.G.; Kokou, K. Multitemporal Analysis of Coastal Erosion Based on Multisource Satellite Images in the South of the Mono Transboundary Biosphere Reserve in Togo (West Africa). Open Access Libr. J. 2018, 5, e4526. [CrossRef]

36. Blivi, A. Vulnérabilité de la côte togolaise à l'élévation du niveau marin: Une analyse de prévision et d'impact. Patrimoines 2000, 10, 643-660.

37. Dossou, K.M.R.; Gléhouenou-Dossou, B. The Vulnerability to climate change of Cotonou (Benin): The rise in sea level. Environ. Urban. Int. Inst. Environ. Dev. (IIED) 2007, 19, 65-79. [CrossRef] 